\title{
Immunoexpression of Cell Proliferation Markers in Oral Squamous Cell Carcinoma
}

\author{
Inmunoexpresiones de Marcadores de Proliferación Celular \\ en Carcinoma de Células Escamosas Orales
}

\author{
Joabe dos Santos Pereira*; Keila Martha Amorim Barroso*; Cassiano Francisco Weege Nonaka ${ }^{* * *}$; \\ Leão Pereira Pinto ${ }^{*+* t}$ \& Lélia Batista de Souza ${ }^{*+* t}$
}

PEREIRA, J. S.; BARROSO, K. M. A.; NONAKA, C. F. W.; PINTO, L. P. \& DE SOUZA, L. B. Immunoexpression of cell proliferation markers in oral squamous cell carcinoma. Int. J. Odontostomat., 10(3):513-520, 2016.

ABSTRACT: This study aimed to assess the immunoexpression of cell proliferation markers (Ki-67 and Mcm-2) in oral tongue cancer, correlating it with patients' age and prognostic indicators. Sample was composed of 22 cases under 40 years and 22 over 50 years of age. Clinical staging and histological grade of malignancy were obtained. Cell proliferation was evaluated through labeling indices. Statistical analysis was performed $(p<0.05$ for statistical significance). Most young patients were stages III/IV ( $n=13 / 65 \%)$ and most older patients were stages I/II ( $n=11 / 61.1 \%)(p>0.05)$. Mean Ki-67-LI in young and older patients was $42.4 \%$ and $44.15 \%$, respectively ( $p>0.05)$. Mean Mcm-2-LI was higher in older (63.6 \%) than in young patients $(55.75 \%)(p<0.05)$. We found that young patients presented more aggressive lesions in comparison to older patients, however Mcm-2 expression was significantly higher in older than in young patients. SCC of tongue can be more aggressive in young patients, and this may not be related to cell proliferation. Our findings for $\mathrm{Mcm}-2 \mathrm{LI}$ and $\mathrm{Ki}-67 \mathrm{LI}$ suggests that Mcm-2 could be a more sensitive marker for cell proliferation.

KEY WORDS: oral cancer, squamous cell carcinoma, age groups, ki-67 antigen, biological markers, prognosis.

\section{INTRODUCTION}

Oral squamous cell carcinoma (OSCC) is a malignant neoplasm of epithelial origin, which has a propensity for early metastasis to regional lymph nodes. Although only $1 \%$ to $6 \%$ of OSCCs occur in individuals younger than 40 years (Ribeiro et al., 2011), evidence accumulated over the last three decades suggests an increase in the incidence of these tumors among young subjects (Popovtzer et al., 2004; Sun et al., 2015).

The etiology, clinical features and biological behavior of OSCC in young patients differ from that observed in older patients (Popovtzer et al. ; Ribeiro et al. ), suggesting a more aggressive course of oral cancer in the former. Increasing efforts have been made to identify biological indicators of OSCC in young subjects in an attempt to better understand the biological nature and aggressiveness of this tumor in these patients (Kodani et al., 2003; Gonzalez-Moles et al., 2010).

Disordered cell proliferation is one of the most important biological mechanisms in oncogenesis. The proportion of actively dividing cells is called the growth fraction and can be assessed using $\mathrm{Ki}-67$, a protein that acts in cell cycle regulation (Motta et al., 2009; Gonzalez-Moles et al.; Gontarz et al., 2015). Ki-67 is expressed during all phases of the cell cycle, except for the G0 and early G1 phases. Analysis of the expression of Ki-67 has been shown to be efficient for the rapid and accessible assessment of the proportion of proliferating cells in tumor tissues (Gonzalez-Moles et al.; Freudlsperger et al., 2011; Oliveira et al., 2011).

Professor, Department of Pathology, Federal University of Rio Grande do Norte, Natal, Rio Grande do Norte, Brazil

* Professor, Department of Dentistry, Federal University of Campina Grande, Patos, Paraíba, Brazil

*** Professor, Post-graduation Program of Dentistry, Department of Dentistry, State University of Paraíba, Campina Grande, Paraíba, Brazil

**** Professor, Post-graduation Program of Oral Pathology, Department of Dentistry, Federal University of Rio Grande do Norte, Natal, Rio Grande do Norte, Brazil 
Other cell cycle regulatory proteins are deregulated in several human cancers, including proteins that promote the initiation of DNA synthesis such as minichromosome maintenance $(\mathrm{Mcm})$ proteins (TorresRendon et al., 2009; Gonzalez-Moles et al.). This protein is an essential licensing factor for DNA replication and limits this replication until the cell cycle is completed (Wang et al., 2009; Gueiros et al., 2011). Mcm-2 is a putative marker of cell cycle phase and its aberrant expression in dysplasias and malignancies permits the use of this protein as an adjuvant marker for the assessment of malignant behavior, survival, and cancer prognosis (Kodani et al. ; Wang et al. ; Gouvêa et al., 2013). The combined application of Mcm-2 and Ki-67 may provide additional information about epithelial proliferation rates (Huang et al., 2011; Gouvêa et al. ).

The aim of the present study was to evaluate the cell proliferation index by immunohistochemical expression of $\mathrm{Ki}-67$ and $\mathrm{Mcm}-2$ in SCC of the tongue in two groups of patients: under 40 years and over 50 years of age. The purpose was to determine whether a difference in cell proliferation exists between these two age groups and to correlate the findings with clinical stage, histological grade of malignancy, and prognostic indicators of SCC.

\section{MATERIAL AND METHOD}

This study was conducted according to the World Medical Association Declaration of Helsinki (latest version) and the experiments were undertaken with the understanding and written consent of each subject. In addition, this study has been independently reviewed and approved by the Research Ethics Committee of Dr Luiz Antônio Hospital, Natal, Rio Grande do Norte, Brazil (protocol 051/051/2009).

Forty four cases of SCC of the oral tongue were randomly selected for this study. The specimens were obtained from the files of the Dr Luiz Antônio Hospital and of the Oral Pathology Department, Federal University of Rio Grande do Norte, Natal, Rio Grande do Norte, Brazil. These specimens were divided into two groups: a young group consisting of 22 cases of SCC diagnosed in patients aged 40 or less, and an older group consisting of 22 cases of SCC diagnosed in patients older than 50 years. Information regarding the presence or absence of regional nodal metastasis and the clinical tumor-node-metastasis (TNM - latest version) stage was collected from the patient records.
The histological grade of malignancy was analyzed based on a histological grading system proposed previously (Bryne, 1998). For purpose of statistical analysis, the cases were classified as high grade (total score $>8$ ) and low grade (total score $\leq 8$ ) of malignancy as adapted from da Silveira et al. (2010).

Immunohistochemistry. For immunohistochemical study, $3 \mathrm{~mm}$ thick sections were obtained from paraffinembedded tissue blocks. The sections were incubated with the following primary antibodies: anti-Ki-67 (clone MIB-1, Dako, Carpinteria, CA, USA), antigen retrieval at Steamer (EDTA, pH 8.0, 60 min), dilution 1:50, and incubation for $60 \mathrm{~min}$; anti-Mcm-2 (clone CRCT-2, Novocastra, Newcastle Upon Tyne, UK), antigen retrieval at Pascal (EDTA, pH 8.0, $121^{\circ} \mathrm{C}, 3 \mathrm{~min}$ ), dilution 1:25, and incubation for $60 \mathrm{~min}$.

After treatment with normal serum, the tissue sections were incubated in a moist chamber with the primary antibodies. The tissue sections were then washed twice in PBS and treated with the labeled streptavidin-biotin complex (LSAB+ System-HRP; Dako, Carpinteria, CA, USA) at room temperature to bind the primary antibodies. Peroxidase activity was visualized by immersing the tissue sections in diaminobenzidine (Liquid DAB+ Substrate; Dako, Carpinteria, CA, USA). Finally, the tissue sections were counterstained with Mayer's hematoxylin. Positive and negative controls were performed according to the manufacturer's instructions.

Assessment of immunostaining and statistical analysis. Tissue sections were examined in a blind fashion by two observers under a light microscope (Olympus CX31, Olympus Japan Co., Tokyo, Japan). Cell proliferation was evaluated by establishing labeling indices (LI) for Ki-67 and Mcm-2. Briefly, tissue sections were examined under a light microscope at x1000 magnification and 1000 epithelial neoplastic cells were counted in different fields at the deepest invasion front of the tumor, as suggested by Bryne. The Ki-67 and Mcm-2 LI are expressed as the percentage of immunostained nuclei in relation to the total number of nuclei counted.

The results were analyzed statistically using the Statistical Package for the Social Sciences (version 20.0; SPSS Inc., Chicago, IL, USA). For statistical analysis, clinical stages I and II were combined into one group and stages III and IV into another group because no difference in metastasis was observed between groups. Clinical stage and histological grade 
of malignancy were compared by the chi-square test. The Ki-67 and Mcm-2-LI were evaluated by the nonparametric Mann-Whitney U test. The Spearman correlation test was applied to determine possible correlations between $\mathrm{Ki}-67-\mathrm{LI}$ and $\mathrm{Mcm}-2-\mathrm{LI}$. For all tests, a $p$ value $<0.05$ was considered to indicate statistical significance.

\section{RESULTS}

Clinical and morphological analysis. In the group of young patients, TNM stage data were evaluated in 20 cases. Three $(15 \%)$ cases were classified as stage I, four (20\%) as stage II, seven (35\%) as stage III, and six (30\%) as stage IV. In the group of older patients, TNM stage data were assessed in 18 cases. Four $(22.2$ $\%)$ cases were classified as stage I, seven (38.9 \%) as stage II, four $(22.2 \%)$ as stage III, and three (16.7 \%) as stage IV. Statistical analysis did not reveal a significant difference in clinical stage between groups $(p=0.112$, Chi-square test) .

With respect to histological grade of malignancy, the distribution of lesions was similar in young and older patients with low-grade $(42.9 \%$ and $57.1 \%$, respectively) and high-grade tumors (56.5\% and 43.5 $\%$, respectively) ( $p=0.371$, Chi-square test).

Ki-67 labeling index. Assessment of cell proliferation with anti-Ki-67 antibody in young patients with SCC of
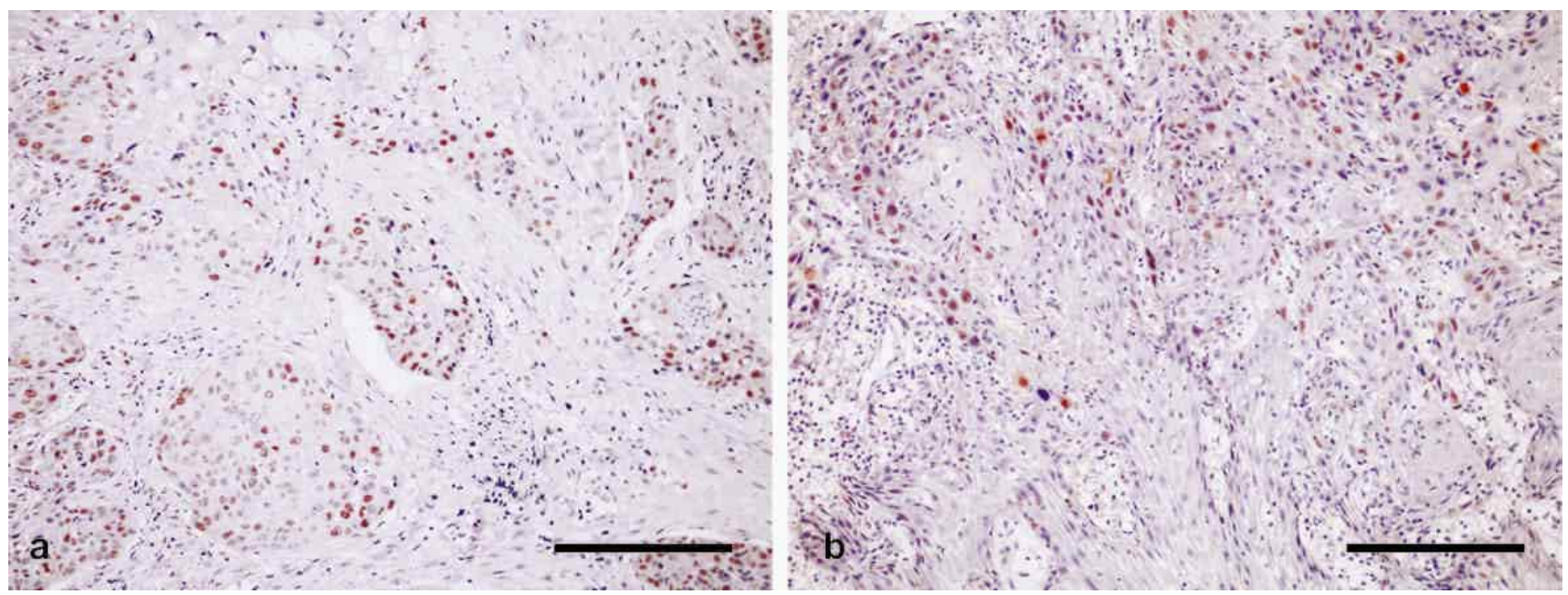

Fig. $1 \mathrm{Ki}-67$ immunostaining in squamous cell carcinoma of the tongue (a) Intense and diffuse immunostaining; low grade; young patient $(\mathrm{LSAB}, \mathrm{Bar}=100 \mu \mathrm{m})(\mathrm{b})$ Moderate immunostaining mainly situated in the deepest invasion front of the tumor; high grade; older patient (LSAB, Bar $=100 \mu \mathrm{m})$
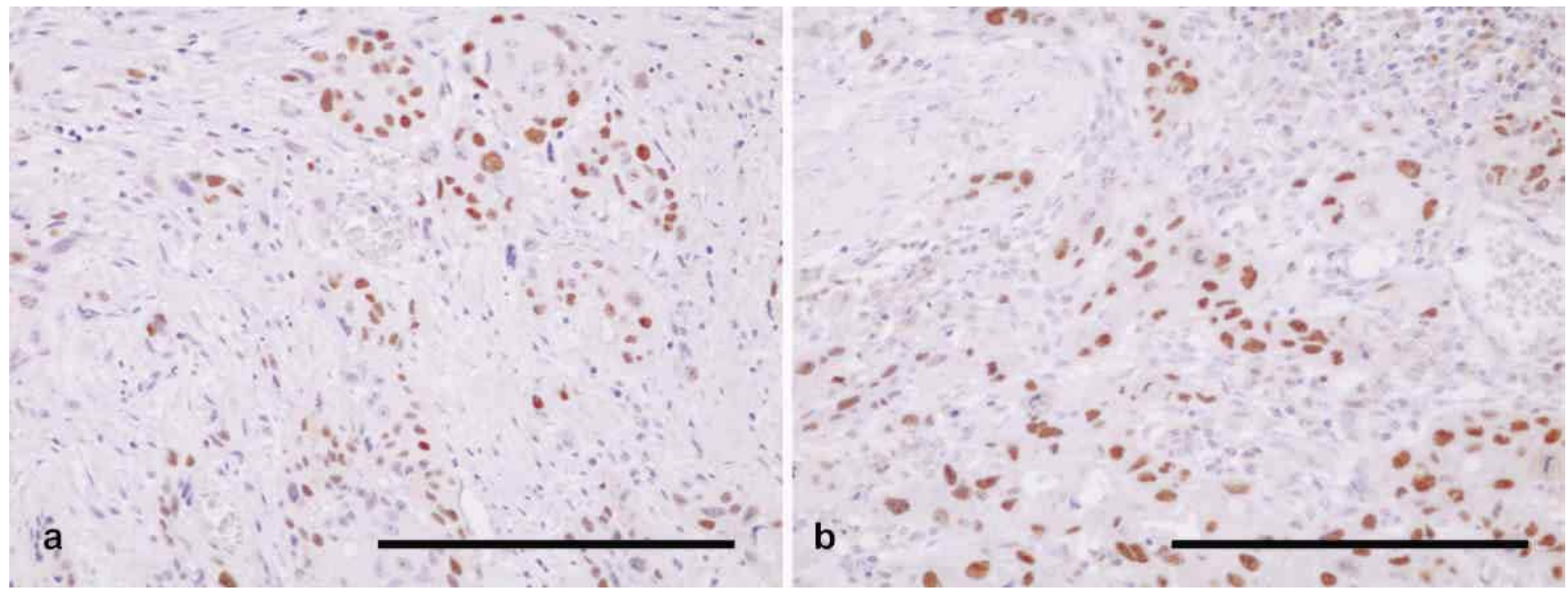

Fig. 2 Mcm-2 immunostaining in squamous cell carcinoma of the tongue (a) Intense nuclear immunostaining; high grade; young patient $(\mathrm{LSAB}, \mathrm{Bar}=100 \mu \mathrm{m})(\mathrm{b})$ Intense nuclear immunostaining; high grade; older patient $(\mathrm{LSAB}, \mathrm{Bar}=100 \mu \mathrm{m})$ 


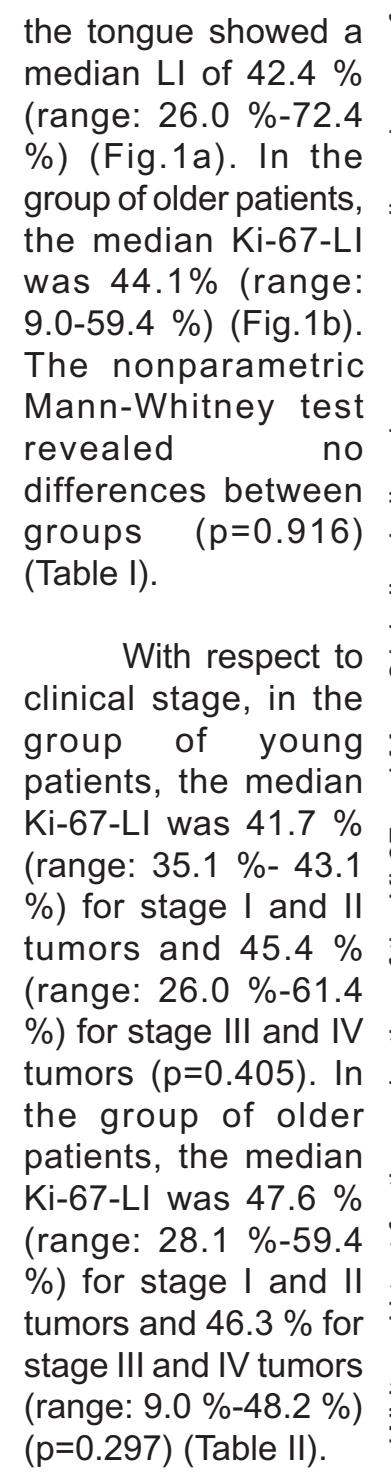

Regarding histological grade of malignancy, in the group of young patients, low-grade tumors exhibited a median Ki-67-LI of $42.8 \%$ (range: $26.5 \%-72.4$ $\%)$ and high-grade tumors had a median Ki-67-LI of $41.5 \%$ (range: $26.0 \%-61.4$ $\%)(p=0.920)$. In the group of older patients, the mean Ki-67-LI was $40.7 \%$ (range: $12.8 \%$ $54.3 \%)$ for low-grade

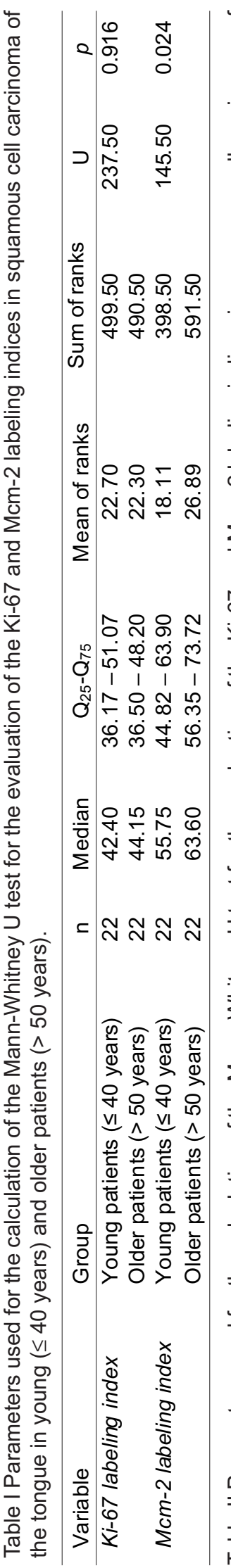


tumors and $46.5 \%$ (range: $9.0 \%-59.4 \%$ ) for highgrade tumors $(p=0.355)$ (Table II).

Mcm-2 labeling index. The evaluation of cell proliferation using anti-Mcm-2 antibody in young patients with SCC of the tongue revealed a median $\mathrm{LI}$ of $55.7 \%$ (range: $31.9 \%-80.9 \%$ ) (Fig. 2a). In the group of older patients, the median Mcm-2-LI was $63.6 \%$ (range: $8.5 \%-93.2 \%$ ) (Fig. 2b). This difference between groups was significant $(p=0.024$, nonparametric Mann-Whitney test) (Table I).

Regarding clinical stage, in the group of young patients, the median Mcm-2-LI was $47.5 \%$ (range: 31.9 $\%-61.9 \%$ ) for stage I and II tumors and $55.8 \%$ (range: $39.4 \%-69.1 \%)$ for stage III and IV tumors ( $p=0.104)$. In the group of older patients, the median Mcm-2-LI was $71.3 \%$ (range: $47.4 \%-93.2 \%$ ) for stage I and II tumors and $61.3 \%$ (range: $8.5 \%-70.3 \%$ ) for stage III and IV tumors $(p=0.160)$ (Table II).

With respect to histological grade of malignancy, in the group of young patients, low-grade tumors had a median Mcm-2-LI of $57.5 \%$ (range: $31.9 \%-80.9 \%$ ) and high-grade tumors had a median Mcm-2-LI of 55.7 $\%$ (range: $39.4 \%-69.2 \%)(p=0.920)$. In the group of older patients, low-grade tumors exhibited a median Mcm-2-LI of $63.3 \%$ (range: $8.5 \%-86.5 \%$ ) and highgrade tumors had a median Mcm-2-LI of $63.6 \%$ (range: $45.9 \%-93.2 \%)(p=0.355)$ (Table II).

Combined analysis of the 44 cases of tongue SCC using Spearman's correlation test revealed a weak positive correlation between $\mathrm{Ki}-67-\mathrm{LI}$ and $\mathrm{Mcm}-$ 2-LI ( $r=0.325 ; p=0.032)$.

The $\mathrm{Mcm}-2 / \mathrm{Ki}-67$ ratio was 1.44 for stage I and II tumors and 1.8 for stage III and IV tumors. With respect to histological grade of malignancy, this ratio was 1.58 for cases of low-grade malignancy and 1.61 for cases of high-grade malignancy. None of these correlations was statistically significant $(p=0.430$ and $p=0.613$, respectively; nonparametric Mann-Whitney test).

\section{DISCUSSION}

OSCC is the sixth most frequent cancer in humans. Therefore, several efforts are being made to identify more specific markers of the biological nature and aggressiveness of this tumor (Jerjes et al., 2010). The present study analyzed the clinical and morphological features and $\mathrm{Ki}-67$ and $\mathrm{Mcm}-2$ immunostaining in two groups of patients with tongue SCC: patients aged 40 years or less (young subjects) and patients aged 50 or older (older patients).

Most of the young patients had stage III or IV SCC of the tongue, whereas most older subjects had stage I or II tumors. In a recent study, patients with OSSC who died because of metastasis were younger than those who died from locoregional tumor invasion (Jerjes et al. ). Several studies have shown that young patients with OSCC have a more advanced stage and a poorer prognosis than older patients (Garavello et al., 2007; Jerjes et al. ; Soudry et al., 2010; Ribeiro et al. ).

A previous report observed two distinct patterns of biological behavior of SCC in the group of young patients: an aggressive course associated with poor survival, and an indolent course associated with long survival. The authors suggested that tumor biology and pathogenesis may be related to age, producing a more aggressive tumor behavior in the young group that may represent a specific and independent type of this neoplasm (Popovtzer et al. ). The results of these studies seem to indicate that OSCCs are more aggressive in younger patients.

In the present study, no significant difference was observed between patient age and histological grade of the tumor $(p=0.371)$. Similar results have been reported by others authors (Garavello et al.; Soudry et al. ; Bachar et al., 2011).

Studies have reported a high correlation between the expression of Ki-67 and tumor progression, metastasis and poor prognosis (Tumuluri et al., 2002; Kurokawa et al., 2005; Gueiros et al. ). In the present study, no significant difference in Ki-67 expression was observed between young and older patients with SCC of the tongue. In a previous similar study, with a different sample, our group also failed to observe such significant difference (Benevenuto et al., 2012). Similarly, others authors, investigating the immunoexpression of Ki-67 in patients with OSCC, observed no difference between young and older patients (Tumuluri et al. ; Silva et al., 2008; Gonzalez-Moles et al. ).

According to our findings, no association between clinical stage and $\mathrm{Ki}-67-\mathrm{LI}$ was observed in young or older patients. Gontarz et al. in a study with patients from 23 to 81 years old, did not find association between clinical stage (UICC) and $\mathrm{KI}-67$ expression. According to these authors, the predictive value of $\mathrm{Ki}$ - 
67 is still controversial. These results are in contrast with others authors, who found higher Ki-67-LI in more advanced OSCCs (stages III and IV) compared to earlystage tumors (I and II) (Tumuluri et al. ; Silva et al. ).

Other studies demonstrated higher Ki-67 immunostaining to be related to a higher frequency of metastasis in OSCCs (Myoung et al., 2006; Gueiros et al. ). Although the prognostic value of cell proliferation markers such as $\mathrm{Ki}-67$ has been recognized for various tumors, it remains uncertain whether these markers are truly correlated with the clinical behavior of the tumor (Liu et al., 2003; Gonzalez-Moles et al. ).

Analysis of Ki-67 immunostaining according to histological grade of malignancy revealed no statistically significant differences in either of the age groups studied. Similar reports found no significant differences in Ki-67-LI between different histological grades of malignancy of OSCC (Motta et al. ; TorresRendon et al. ; Benevenuto et al.).

In our study, analysis of cell proliferation in SCC of the tongue based on the expression of $\mathrm{Mcm}-2$ revealed significant differences between young and older patients $(p=0.024)$. Recent study evaluated Mcm2 immunoreactivity and mRNA expression in normal intestinal mucosa, adenomas and adenocarcinomas of the colon and observed higher expression of this protein in older patients who had high-grade dysplasias (Wang et al. ).

According to the present research, the Mcm-2$\mathrm{LI}$ of tongue SCC was greater than the Ki-67-LI, regardless of clinical stage or histological grade. Similar results have been reported in other studies on OSCC (Kodani et al. ; Scott et al., 2006; Torres-Rendon et al. ) and SCC of the tongue (Gueiros et al. ). One of these studies detected expression of Mcm-2 in normal and neoplastic cells even during the early $\mathrm{G} 1$ phase, whereas Ki-67 was undetectable at this stage (Kodani et al. ). This fact may explain the higher $\mathrm{Mcm}-2-\mathrm{LI}$ seen in the tongue SCC cases studied here.

The combined analysis of the 44 cases of tongue SCC showed a weak positive correlation between Ki67-LI and Mcm-2-LI. Recent report evaluated the expression of $\mathrm{Mcm}-2$ and $\mathrm{Ki}-67$ in oral epithelial dysplasia and OSCC, and also found a positive correlation between the LI of these markers (Scott et al. ). Other authors, analyzing the immunoexpression of Ki-67, Mcm-2 and geminin in specimens of normal oral mucosa, oral epithelial dysplasia and OSCC, observed a linear correlation between $\mathrm{Mcm}-2$ and $\mathrm{Ki}-$ 67 and between geminin and Ki-67 in all specimens analyzed (Torres-Rendon et al. ). The correlations observed in these studies suggest that, despite different functions, $\mathrm{Mcm}-2$ can be used as a more sensitive cell proliferation marker than $\mathrm{Ki}-67$.

The present study showed a trend towards higher Mcm-2/Ki-67 ratios in high-grade SCC of the tongue compared to low-grade tumors and in more advanced tumors compared to early-stage tumors. Results similar to those observed in the present study have been reported previously (Torres-Rendon et al. ). In addition to the observation of higher Ki-67, Mcm2 and geminin $\mathrm{LI}$ in dysplasia and carcinoma specimens compared to normal mucosa, these authors found a higher $\mathrm{Mcm}-2 / \mathrm{Ki}-67$ ratio in oral epithelial dysplasias that progressed to OSSCs when compared to dysplasias that did not undergo malignant transformation during follow-up. This higher $\mathrm{Mcm}-2 /$ $\mathrm{Ki}-67$ ratio observed in dysplasia specimens (to a lesser extent) and OSCCs (to a greater extent) may explain the difference seen in the present study between histological grades of malignancy in SCC of the tongue.

This study observed higher cell proliferation in older than in young patients with SCC of the tongue, particularly through Mcm-2. Otherwise, the group of young patients presented more advanced clinical stages indicating that SSC of the tongue could be more aggressive in younger patients. This fact may not be associated to cell proliferation. Furthermore, the higher $\mathrm{Mcm}-2-\mathrm{LI}$ compared to the Ki-67-LI, together with the positive correlation between these proteins and the higher Mcm-2/Ki-67 ratio, suggests that Mcm-2 is a sensitive marker for the assessment of cell proliferation in SCC of the tongue.

PEREIRA, J. S.; BARROSO, K. M. A.; NONAKA, C. F. W.; PINTO, L. P. \& DE SOUZA, L. B. Inmunoexpresiones de marcadores de proliferación celular en carcinoma de células escamosas oral. Int. J. Odontostomat., 10(3):513-520, 2016.

RESUMEN: Este estudio tuvo como objetivo evaluar la inmunoexpresión de marcadores de proliferación celular (Ki-67 y Mcm-2) en el cáncer de lengua oral, correlacionándolo con la edad de los pacientes y los indicadores pronósticos. La muestra estuvo compuesta por 22 personas menores de 40 años y 22 personas mayores de 50 años. Se identificaron los estadios clínicos y el grado histológico de malignidad. La proliferación celular se evaluó mediante índices de marcado. Se realizó análisis estadísti- 
co ( $p<0,05$ para significación estadística). La mayoría de los pacientes jóvenes eran estadios III / IV ( $n=13 / 65 \%$ ) y la mayoría de los pacientes mayores eran estadios I / II $(n=11$ / 61,1\%) ( $p>0,05)$. La media de Ki-67-LI en pacientes jóvenes y mayores fue $42,4 \%$ y $44,15 \%$, respectivamente ( $p>$ $0,05)$. La media de Mcm-2-LI fue mayor en pacientes mayores $(63,6 \%)$ que en pacientes jóvenes $(55,75 \%)(p<0,05)$. Se encontró que los pacientes jóvenes presentaron lesiones más agresivas en comparación con los pacientes mayores, sin embargo la expresión de $\mathrm{Mcm}-2$ fue significativamente mayor en pacientes mayores que en pacientes jóvenes. SCC de la lengua puede ser más agresivo en pacientes jóvenes, y esto no puede estar relacionado con la proliferación celular. Nuestros hallazgos para Mcm-2 LI y Ki-67 LI sugieren que Mcm-2 podría ser un marcador más sensible para la proliferación celular.

PALABRAS CLAVE: cáncer oral, carcinoma de células escamosas, grupos de edad, antígeno ki-67, marcadores biológicos, pronóstico.

\section{REFERENCES}

Bachar, G.; Hod, R.; Goldstein, D. P.; Irish, J. C.; Gullane, P. J.; Brown, D.; Gilbert, R. W.; Hadar, T.; Feinmesser, R. \& Shpitzer, T. Outcome of oral tongue squamous cell carcinoma in patients with and without known risk factors. Oral Oncol., 47(1):45-50, 2011.

Benevenuto, T. G.; Nonaka, C. F.; Pinto, L. P. \& de Souza, L. B. Immunohistochemical comparative analysis of cell proliferation and angiogenic index in squamous cell carcinomas of the tongue between young and older patients. Appl. Immunohistochem. Mol. Morphol., 20(3):291-7, 2012.

Bryne, M. Is the invasive front of an oral carcinoma the most important area for prognostication? Oral Dis., 4(2):70-7, 1998.

da Silveira, E. J.; Miguel, M. C.; Lima, K. C.; Freitas, R. de A.; de Morais, M. de L. \& Queiroz, L. M. Analysis of local immunity in squamous cell carcinoma of the tongue and lower lip. Exp. Mol. Pathol., 88(1):171-5, 2010.

Freudlsperger, C.; Rohleder, S. E.; Reinert, S. \& Hoffmann, $\mathrm{J}$. Predictive value of high $\mathrm{Ki}-67$ expression in stage I oral squamous cell carcinoma specimens after primary surgery. Head Neck, 33(5):668-72, 2011.

Garavello, W.; Spreafico, R. \& Gaini, R. M. Oral tongue cancer in young patients: a matched analysis. Oral Oncol., 43(9):894-7, 2007.
Gontarz, M.; Wyszyn'ska-Pawelec, G.; Zapa?a, J.; Czopek, J.; Lazar, A. \& Tomaszewska, R. Immunohistochemical predictors in squamous cell carcinoma of the tongue and floor of the mouth. Head Neck, 38 Suppl. 1:E74753, 2016.

Gonzalez-Moles, M. A.; Ruiz-Avila, I.; Gil-Montoya, J. A.; Esteban, F. \& Bravo, M. Analysis of Ki-67 expression in oral squamous cell carcinoma: why $\mathrm{Ki}-67$ is not a prognostic indicator. Oral Oncol., 46(7):525-30, 2010.

Gouvêa, A. F.; Santos Silva, A. R.; Speight, P. M.; Hunter, K.; Carlos, R.; Vargas, P. A.; de Almeida, O. P. \& Lopes, M. A. High incidence of DNA ploidy abnormalities and increased $\mathrm{Mcm} 2$ expression may predict malignant change in oral proliferative verrucous leukoplakia. Histopathology, 62(4):551-62, 2013.

Gueiros, L. A.; Coletta, R. D.; Kowalski, L. P. \& Lopes, M. A. Clinicopathological features and proliferation markers in tongue squamous cell carcinomas. Int. J. Oral Maxillofac. Surg., 40(5):510-5, 2011.

Huang, B.; Hu, B.; Su, M.; Tian, D.; Guo, Y.; Lian, S.; Liu, Z.; Wu, X.; Li, Q.; Zheng, R. \& Gao, Y. Potential role of minichromosome maintenance protein 2 as a screening biomarker in esophageal cancer high-risk population in China. Hum. Pathol., 42(6):808-16, 2011.

Jerjes, W.; Upile, T.; Petrie, A.; Riskalla, A.; Hamdoon, Z.; Vourvachis, M.; Karavidas, K.; Jay, A.; Sandison, A.; Thomas, G. J.; Kalavrezos, N. \& Hopper, C. Clinicopathological parameters, recurrence, locoregional and distant metastasis in 115 T1-T2 oral squamous cell carcinoma patients. Head Neck Oncol., 2:9, 2010.

Kodani, I.; Osaki, M.; Shomori, K.; Araki, K.; Goto, E.; Ryoke, K. \& Ito, H. Minichromosome maintenance 2 expression is correlated with mode of invasion and prognosis in oral squamous cell carcinomas. J. Oral Pathol. Med., 32(8):468-74, 2003.

Kurokawa, H.; Zhang, M.; Matsumoto, S.; Yamashita, Y.; Tanaka, T.; Tomoyose, T.; Takano, H.; Funaki, K.; Fukuyama, H.; Takahashi, T. \& Sakoda, S. The relationship of the histologic grade at the deep invasive front and the expression of Ki-67 antigen and p53 protein in oral squamous cell carcinoma. J. Oral Pathol. Med., 34(10):602-7, 2005.

Liu, M.; Lawson, G.; Delos, M.; Jamart, J.; Ide, C.; Coche, E.; Weynand, B.; Desuter, G.; Hamoir, M.; Remacle, M. \& Marbaix, E. Predictive value of the fraction of cancer cells immunolabeled for proliferating cell nuclear antigen or Ki67 in biopsies of head and neck carcinomas to identify lymph node metastasis: comparison with clinical and radiologic examinations. Head Neck, 25(4):280-8, 2003. 
Motta, R. da R.; Zettler, C. G.; Cambruzzi, E.; Jotz, G. P. \& Berni, R. B. Ki-67 and p53 correlation prognostic value in squamous cell carcinomas of the oral cavity and tongue. Braz. J. Otorhinolaryngol., 75(4):544-9, 2009.

Myoung, H.; Kim, M. J.; Lee, J. H.; Ok, Y. J.; Paeng, J. Y. \& Yun, P. Y. Correlation of proliferative markers (Ki-67 and PCNA) with survival and lymph node metastasis in oral squamous cell carcinoma: a clinical and histopathological analysis of 113 patients. Int. J. Oral Maxillofac. Surg., 35(11):1005-10, 2006.

Oliveira, L. R. \& Ribeiro-Silva, A. Prognostic significance of immunohistochemical biomarkers in oral squamous cell carcinoma. Int. J. Oral Maxillofac. Surg., 40(3):298-307, 2011.

Popovtzer, A.; Shpitzer, T.; Bahar, G.; Marshak, G.; Ulanovski, D. \& Feinmesser, R. Squamous cell carcinoma of the oral tongue in young patients. Laryngoscope, 114(5):9157, 2004.

Ribeiro, C. M.; Gueiros, L. A.; Leon, J. E.; do Carmo Abreu e Lima, M.; de Almeida, O. P. \& Leão, J. C. Oral squamous cell carcinoma in a 7-year-old Brazilian boy. Int. J. Oral Maxillofac. Surg., 40(9):994-7, 2011.

Scott, I. S.; Odell, E.; Chatrath, P.; Morris, L. S.; Davies, R. J.; Vowler, S. L.; Laskey, R. A. \& Coleman, N. A minimally invasive immunocytochemical approach to early detection of oral squamous cell carcinoma and dysplasia. Br. J. Cancer, 94(8):1170-5, 2006.

Silva, S. D.; Perez, D. E.; Alves, F. A.; Nishimoto, I. N.; Pinto, C. A.; Kowalski, L. P. \& Graner, E. ErbB2 and fatty acid synthase (FAS) expression in 102 squamous cell carcinomas of the tongue: correlation with clinical outcomes. Oral Oncol., 44(5):484-90, 2008.

Soudry, E.; Preis, M.; Hod, R.; Hamzany, Y.; Hadar, T.; Bahar, G.; Strenov, Y. \& Shpitzer, T. Squamous cell carcinoma of the oral tongue in patients younger than 30 years: clinicopathologic features and outcome. Clin. Otolaryngol., 35(4):307-12, 2010.

Sun, Q.; Fang, Q. \& Guo, S. A comparison of oral squamous cell carcinoma between young and old patients in a single medical center in China. Int. J. Clin. Exp. Med., 8(8):12418-23, 2015

Torres-Rendon, A.; Roy, S.; Craig, G. T. \& Speight, P. M. Expression of Mcm2, geminin and Ki67 in normal oral mucosa, oral epithelial dysplasias and their corresponding squamous-cell carcinomas. Br. J. Cancer, 100(7):1128-34, 2009.

Tumuluri, V.; Thomas, G. A. \& Fraser, I. S. Analysis of the Ki67 antigen at the invasive tumour front of human oral squamous cell carcinoma. J. Oral Pathol. Med., 31(10):598-604, 2002.

Wang, Y.; Li, Y.; Zhang, W. Y.; Xia, Q. J.; Li, H.G.; Wang, R.; Yang, L.; Sun, X. F. \& Zhou, Z. G. mRNA expression of minichromosome maintenance 2 in colonic adenoma and adenocarcinoma. Eur. J. Cancer Prev., 18(1):40-5, 2009.

Correspondence to:

Lélia Batista de Souza

Universidade Federal do Rio Grande do Norte

Departamento de Odontologia

Programa de Pós- Graduação em Patologia Oral

Av. Senador Salgado Filho, 1787

Lagoa Nova

Natal/RN, CEP 59056-000

BRASIL

E-mail: lelia.souza@pesquisador.cnpq.br

Received: 24-05-2016

Accepted: 29-08-2016 